\title{
The Effectiveness of Cognitive Behavioral Group Therapy on Depression, Hope and Adjustment in Patients with Hepatitis B
}

\author{
Hossein Shareh, ${ }^{1,{ }^{*}}$ Zahra Robati, ${ }^{2}$ Fereshteh Oladi, ${ }^{3}$ and Vahid Jafarnia ${ }^{3}$ \\ ${ }^{1}$ Department of Educational Sciences, Faculty of Literature and Humanities, Hakim Sabzevari University, Sabzevar, IR Iran \\ ${ }^{2}$ Department of Psychology and Educational Sciences, Semnan University, Semnan, IR Iran \\ ${ }^{3}$ Department of Psychology and Educational Sciences, Torbatjam Branch, Islamic Azad University, Torbatjam, IR Iran \\ "Corresponding author: Hossein Shareh, Assistant Professor of Clinical Psychology, Educational Department, Faculty of Literature and Humanities, Hakim Sabzevari \\ University, Sabzevar, Iran. E-mail: hsharreh@yahoo.com.au
}

Received 2016 October 21; Revised 2017 January 03; Accepted 2017 April 18.

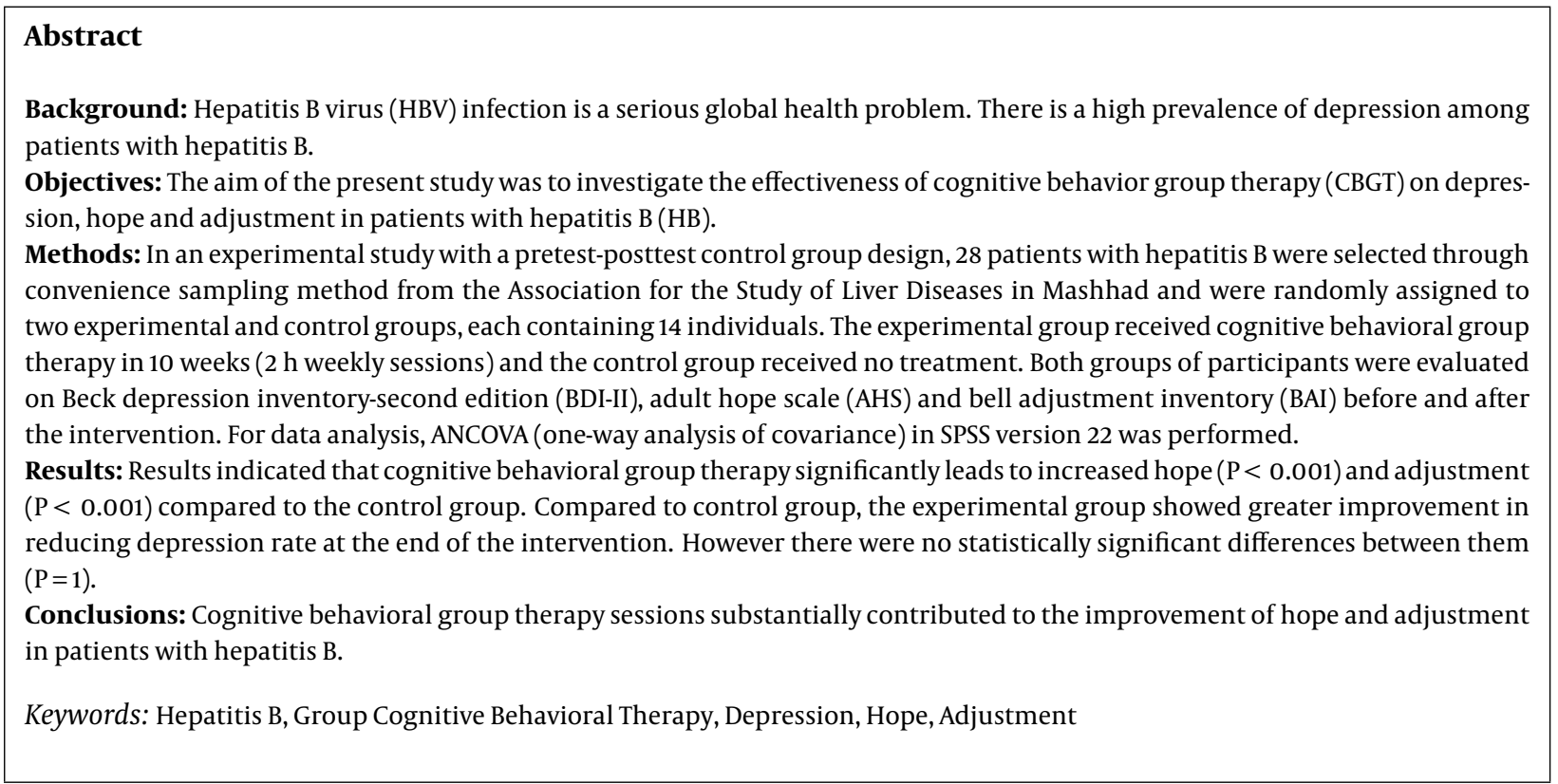

\section{Background}

Hepatitis is an inflammation of the liver. The condition can be self-limiting or can progress to fibrosis (scarring), cirrhosis or liver cancer. There are 5 main hepatitis viruses, referred to as types A, B, C, D and E [1]. HBV (Hepatitis $B$ virus) infection is a serious global health problem, with 2 billion people infected, and 350 million suffering from chronic HBV infection [2-4]. The HBV infection prevalence in Iran estimated $2.14 \%$ (2.55\% in men and $2.03 \%$ in women) [5].

Mood disorders are common problems in chronic diseases including HBV [6, 7]. Frankle [8] believed that depression in people with physical illness is a kind of grief and the reaction to physical conditions. Further, depression and anxiety are among the side effects of interferon which is applied in the treatment of hepatitis B virus infection [913].

In a study, Bonaccorso et al. [14] came to the conclusion that $40 \%$ of the patients with hepatitis $C$ suffer from major depression caused by interferon treatment. Alian et al. [15] demonstrated that there is a high prevalence of depression among patients with hepatitis $B$ and hepatitis $C$ infection, especially patients on interferon therapy.

One of the most important effective factors of health, length of life, improvement and consistency of patients is hope [16]. Hope contains notions of an individualized, future orientation, implies active participation on the part of an individual and references the possibility of a positive outcome [17].

Adjustment to illness can be viewed as the process to maintain a positive view of the self and the world in the face of a health problem [18]. Gaining health in chronic diseases is possible through the establishment of adjustment in various dimensions (physical and psychological) [19]. A large body of research suggests that support from others can facilitate recovery from a physical illness and enhance the ability to cope with and adapt to the consequences of chronic illness [20].

The success of medical treatment of hepatitis requires 
diagnosis and treatment of depression and other psychological problems before and during the treatment [21]. Studies conducted have shown that given the high rates of depression in HBV, a multidisciplinary system which includes mental health professionals helps to treat the patients [22]. Further, psychiatric consultation along with continuing education to patients and their families can be effective in improving physical, social and psychological conditions of these patients [23].

CBT refers to a set of strategies for dealing with mental health problems that has existed for over 40 years and has a huge empirical literature supporting its validity as a psychotherapy approach with typical patients. This large collection of therapeutic approaches are all based on the assumption that cognitive activity affects emotions and behavior and that people can learn to monitor and alter that activity in order to bring about changes in mood and behavior [24].

Empirical studies have demonstrated that this treatment effectively leads to a reduction in the symptoms of anxiety disorders and depression in most patients [25].

CBGT (Cognitive behavioral group therapy) is based on the assumption that adding group factors such as the sharing of knowledge, discovery of the universality of issues, acquisition of hope while observing the improvement of other patients, development of altruism and the desire to help people, correction of one's mistakes through observing and evaluating the behavior of others and also group cohesion can make different types of learning proportionate to each other [26].

Delivering CBT for depression in a group format is a cost-effective alternative to individual treatment [27, 28], bipolar disorder $[29,30]$, obsessive compulsive disorder [31], panic disorder [32], panic disorder with agoraphobia [33], insomnia disorder [34, 35], sexual abuse in girls [36] and post-traumatic stress disorder $[37,38]$.

Several studies have shown the effectiveness of cognitive behavioral group therapy in reducing psychological distress, depression symptoms, anxiety and aggression in chronic medical disorders including acquired immune deficiency syndrome [39], diabetes [40], breast cancer [41, 42], chronic disease [43] and epilepsy [44]. As regards hepatitis B, limited psychological treatments have been provided. For example, in a research conducted by Arvand et al. [45], it was demonstrated that the treatment focused on problem-solving is helpful in reducing the signs and symptoms of depression in patients with hepatitis B. In another study [46], it was revealed that multistage group education programs are effective in raising the awareness of participants regarding the ways of transmission of hepatitis $B$ virus, its prevention and control. The present study investigates the effectiveness of cognitive behavioral group ther- apy in depression, hopefulness and adjustment of patients with hepatitis $\mathrm{B}$.

\section{Methods}

\subsection{Study Design}

The study employed a pretest-posttest experimental design with 2 conditions: 14 patients participated in an experimental condition and 14 patients in a control condition.

The population of interest was patients with hepatitis B who had a file in association for the study of liver diseases in Khorasan Razavi, Iran. Using convenience sampling methods, 28 patients who met inclusion criteria were selected and randomly assigned to the experimental and the control group. Patients who met the following criteria at the start of treatment were eligible for the study:1) aged between 18 to 50 years; 2) the drug prescribed for them should be a kind of beta-interferon and 3) having at least a high school diploma. The experimental group attended the therapy sessions and the control (waiting list) group was asked to wait for treatment. An assistant professor of clinical psychology (the first author) conducted the treatment. All therapy sessions were recorded on audiotape for supervision. For preventing biases, all outcome measures were done by an independent assessor and both groups were kept unaware of each other. Written informed consent was obtained from all participants. Session-by-session treatment protocol is presented in Table 1.

\subsection{Ethical Information}

All procedures followed were in accordance with the ethical standards of the responsible committee on human experimentation (institutional and national) and with the Helsinki declaration of 1975 , as revised in 2000 . The study received ethical approval from the "Research Center of the Islamic Azad University of Torbatjam Branch" and it was done by the agreement of the "Mashhad Association for the Study of Liver Diseases".

\subsection{Outcome Measures}

Beck depression inventory-second edition (BDI-II): Beck depression inventory-second edition (BDI-II) [47] is the revised form of Beck depression inventory that has been developed to assess depression. BDI-II is a 21-item selfreport instrument which is classified into three groups of emotional, cognitive and physical symptoms [48]. The range of scores for each item is between 0 - 3. Total score of BDI-II is between $0-63$. Scores of 0 to 13 indicate lack of depression; scores of 14 to 19 show mild to moderate depression; scores of 20 to 28 indicate moderate to severe 
Table 1. Session-By-Session Treatment Protocol

\begin{tabular}{|c|c|}
\hline Sessions & Content \\
\hline Introductory session & Preparation and determining the structure of the group, definition of goals, discovery of expectations, establishment of group cohesion and coping with the initial anxiety of group members \\
\hline First session & $\begin{array}{l}\text { Introducing the cognitive behavioral approach of emotional disorders especially depression, explaining the biological, psychological and social model of depression, helping the individuals to work on } \\
\text { concerns and discomfort which they bring with them into the group, elimination of resistance to treatment. homework: completing the forms relating to the biological, psychological and social model }\end{array}$ \\
\hline Second session & $\begin{array}{l}\text { Reviewing the previous session's homework, teaching the relationship between activities and mood states, use of behavioral interventions to modify the behavior and improve the mood, providing feedback } \\
\text { and reinforcement for group members, facilitating interactions. homework: completing the schedule of activities and mood rating }\end{array}$ \\
\hline Third session & $\begin{array}{l}\text { Reviewing the previous session's homework, assessing the results and consequences of behavioral modification, determining the mood changes that will be targeted by cognitive interventions, naming and } \\
\text { grading the emotions experienced in existing difficult situations with examples. homework: completing the first two columns of thought record sheet (situations and emotions) }\end{array}$ \\
\hline Fourth session & $\begin{array}{l}\text { Reviewing the previous session's homework, explaining and interpreting "self-talk" as the connector between the situation and emotion with examples of the patient, identifying automatic thoughts and } \\
\text { focus on the thoughts that have the strongest relationship with emotion, identifying and evaluating the existing evidence about automatic thoughts. homework: completing the first four columns of } \\
\text { thought record sheet }\end{array}$ \\
\hline Fifth session & $\begin{array}{l}\text { Reviewing the previous session's homework, introducing the counterevidence through inquiry and examples of the patient, introducing the list of "cognitive distortions" along with examples. homework: } \\
\text { completing the first seven columns of thought record sheet and determining the cognitive distortions }\end{array}$ \\
\hline Sixth session & Reviewing the previous session's homework, introducing the alternative thoughts, application of problem-solving regarding the alternative thoughts. homework: completing the thought record sheets \\
\hline Seventh session & $\begin{array}{l}\text { Reviewing the previous session's homework, discussing behavioral experiment, experiments design that is similar to the example or case of the patient, teaching the imaginal exposure technique to reduce } \\
\text { the fear of biopsy. homework: testing and reviewing its results and consequences }\end{array}$ \\
\hline Eighth session & $\begin{array}{l}\text { Reviewing the previous session's homework, introducing deep cognitions, concept of conditional preasumption and core and important beliefs, using the downward arrow technique. homework: practicing } \\
\text { the downward arrow technique }\end{array}$ \\
\hline Ninth session & $\begin{array}{l}\text { Reviewing the previous session's homework, explaining the relationship between conditional preasumptions and core beliefs through continuum model, introducing the coping strategies associated with } \\
\text { core beliefs. homework: applying alternative coping strategies and monitoring its results }\end{array}$ \\
\hline Tenth session & $\begin{array}{l}\text { Reviewing the previous session's homework, strengthening changes and discussion about the application of skills learned in the group in everyday situations, post treatment follow up and evaluation, } \\
\text { termination }\end{array}$ \\
\hline
\end{tabular}

depression; and scores of 29 to 63 show severe depression [49].

Grothe et al. [50] obtained the internal consistency of over 0.90. In the research performed by Wang and Gorenstein [51], internal consistency of 0.90 and test-retest reliability ranged from 0.73 to 0.96 was reported. Also, Kapci et al. [52] reported the validity coefficient of 0.65 between BDI-II and Beck Hopelessness Scale and Beck Anxiety Inventory. Alpha coefficient of 0.91 and test-retest reliability coefficient of 0.94 with one week interval were obtained by Fata et al. [53] in a sample of 91 people in Iran. Further, Mohammadkhani and Dobson [54] obtained alpha coefficients of 0.92 and 0.93 respectively in outpatients and students in addition to test-retest coefficient of 0.93 with one week interval. In another study, Rajabi and Karjou Kasmaei [55] carried out a factor analysis on BDI-II and reported the Cronbach's alpha coefficients of $0.86,0.84$ and 0.78 respectively for the entire questionnaire, cognitive-emotional factor and factor of negative attitude-physical symptoms. Validity coefficients between the total score of depression with the first and second factors and also between the factors were respectively $0.90,0.95$ and 0.75 . This indicates the construct validity of BDI-II in Iran.

Adult hope scale (AHS): the adult hope scale (AHS) contains 12 items with 8-point scale ranging (from definitely false to definitely true). The range of scores is between 8 and 64. Score 8 indicates the lowest level of hope and score 64 shows the highest level of hope. This scale has been divided into two subscales based on Snyder's cognitive model of hope: 1) agency (i.e., goal-directed energy) and (2) pathways (i.e., planning to accomplish goals). Cron- bach alpha for the total score in 6 samples of college graduates and 2 samples of people under psychological treatment was 0.74 to 0.84 . Test-retest correlation of the whole questionnaire was 0.80 and for the courses of more than 41 weeks, it is greater than this value [56]. Correlations of this questionnaire with Beck hopelessness scale and Beck depression inventory are respectively 0.51 and 0.42 , which suggests the concurrent validity of this questionnaire [57]. In a study by Ghobary et al. [58] on Iran's student population, Cronbach's alpha was obtained $0.82,0.79$ and 0.88 respectively for the whole scale, subscale of factor thinking and strategies. Kermani et al. [59] performed a study on 371 students in Tehran and reported the Cronbach's alpha coefficient of 0.86 .

Bell adjustment inventory (BAI): this questionnaire consists of 160 items and 5 subscales including home adjustment, health adjustment, social adjustment, emotional adjustment and job adjustment. There are 32 questions for each subscale. The subject answers each question in the form of yes, no or I don't know. Score 1 is considered for each question if the correct answer is provided. But if the answer is wrong, score 0 will be given. Adjustment score of each subject is equal to the total points obtained from all the questions. The lower the score achieved by the participant in Bell Adjustment Inventory, the higher the adjustment will be and vice versa. In addition to the total score, adjustment score of the individual can be calculated in each dimension of adjustment, which shows the rate of the individual's adjustment in that dimension. Bell [60] reported the reliability coefficients of $0.91,0.81,0.88$, $0.91,0.85$ and 0.94 respectively for the scales of adjustment 
at home, health adjustment, social adjustment, emotional adjustment, job adjustment and the whole test. The scale has also shown a high validity in distinguishing the normal group from the neurotic group and correlation with Eysenck personality test [61]. In the research conducted by Pourseyyed et al. [62], reliability coefficient between the two halves of the scale was 0.85 in Iranian students.

\subsection{Statistical Methods}

For data analysis, one-way analysis of covariance (ANCOVA) in SPSS version 22 was performed.

\section{Results}

Table 2 shows the descriptive indicators of age, education and data obtained from BDI-II, BAI and AHS implementation in the stage of pretest and posttest for each of control and experimental groups separately. Additionally, $t$ test results have been provided in this table to compare the pretests. This indicates that the two groups are not significantly different in any of the research variables and are equal.

To assess the effectiveness of cognitive behavior group therapy in depression, hope and adjustment of the patients with hepatitis B, ANCOVA was used. Before implementing ANCOVA, the assumption of homogeneity of variances was analyzed and Levene test results showed that there is the possibility of implementing ANCOVA. Results of the analysis of covariance to compare the two experimental and control groups after eliminating the effects of pretest have been provided in Table 3.

ANCOVA results show that cognitive behavior group therapy has led to improved hope, total adjustment, social adjustment and emotional adjustment of the patients with hepatitis B. But comparing the two groups in variables of depression, health adjustment and educational and job adjustment is not significant.

\section{Discussion}

This study investigates the effectiveness of cognitive behavior group therapy in depression, hope and adjustment of patients with hepatitis $\mathrm{B}$. The results indicated that after participating in cognitive behavior group therapy sessions, the amount of hope, total adjustment, social adjustment and emotional adjustment of the patients with hepatitis B increased; but depression, health adjustment and educational and job adjustment showed no significant improvement. These results are consistent with the findings obtained in studies by Molassiotis et al. [39], Rossello and Jimenez-chafey [40], McKiernan et al. [41],
Macrodimitrisa et al. [44], Arvand et al. [45], Khatibian and Shakerian [63], Oladi et al. [64] and Mohammadi Geravand et al. [65], which were conducted regarding the impact of cognitive behavior group therapy on a variety of chronic diseases.

In the study carried out by Oladi et al. [64] 12 sessions of group cognitive behavior intervention improved the components of vitality, social functioning and life quality in patients with coronary heart diseases. Molassiotis et al. [39] conducted a study on 46 patients with HIV. The results suggested that cognitive behavior group therapy has a significant impact on reducing stress, anxiety, anger and depression and also improving the life quality of patients with HIV. In another research, Hassanzade et al. [66] examined 50 patients suffering from breast cancer and concluded that after 12 sessions of cognitive behavior group therapy, the level of health increased and the rate of depression, anxiety, insomnia and vertigo decreased in these patients.

A study has demonstrated that cognitive behavior therapy, through techniques such as relaxation, guided imagery and cognitive restructuring leads to the improvement of cognitions and beliefs of a person about chronic diseases including hepatitis and promotes efficiency and feeling of self-sufficiency and thus increases the individual's hope [67]. Results of the present study which are consistent with the findings achieved by Strawbridge et al. [68] and Snyder [69] confirm this issue. Snyder [69] in a study came to the conclusion that there is a significant correlation between the high level of hopefulness and positive emotions. Patients who have a spirit of hope learn how to deal with the disease faster than others. In this way, they can act as a source of support and information for other patients in the course of their treatment.

Results of the present research concerning the five subscales of adjustment inventory indicate that the greatest changes occurred respectively in the subscales of total adjustment, social adjustment and emotional adjustment. These results are consistent with the findings obtained by Lorig et al. [70] and Lyons et al. [20] who revealed that cognitive behavior therapy reduces the level of disability and use of medical services in patients with chronic diseases and leads to total adjustment of the individual with the chronic disease through increasing the amount of activities and establishing good communication between the individual and those around and also enjoying social protection particularly from the family. Adjustment has a wide range, at the head of which is the social adjustment and social adjustment is also associated with factors such as heredity, environment, family and group membership [71].

In the present study, although the depression score of the subjects attending cognitive behavior group therapy decreased, this reduction was not significant. This may be 
Table 2. Mean and Standard Deviation of the Research Variables in the Pretest and Posttest and t Test Results to Compare the Two Groups in the Pretest

\begin{tabular}{|c|c|c|c|c|c|}
\hline \multirow[b]{2}{*}{ Variables } & \multirow[b]{2}{*}{ Group } & \multicolumn{4}{|c|}{ Posttest } \\
\hline & & Mean \pm SD & $\mathbf{t}$ & Significance Level & Mean \pm SD \\
\hline \multirow{2}{*}{ Age } & Experimental & $30.79 \pm 2.42$ & 0.79 & 0.421 & \\
\hline & Control & $29.36 \pm 2.37$ & 0.79 & 0.421 & \\
\hline \multirow{2}{*}{ Education } & Experimental & $10.57 \pm 2.17$ & 0 & 1 & \\
\hline & Control & $10.57 \pm 1.87$ & 0 & 1 & \\
\hline \multirow{2}{*}{ Depression } & Experimental & $25.29 \pm 10.56$ & 1.14 & 0.264 & $20.05 \pm 9.57$ \\
\hline & Control & $29.57 \pm 9.26$ & 1.4 & 0.264 & $26.07 \pm 7.47$ \\
\hline \multirow{2}{*}{ Hope } & Experimental & $14.07 \pm 4.23$ & 0.69 & 0.494 & $17.64 \pm 3.27$ \\
\hline & Control & $13 \pm 3.94$ & 0.69 & 0.494 & $13.93 \pm 2.46$ \\
\hline \multirow{2}{*}{ Adjustment at home } & Experimental & $12.93 \pm 3.75$ & 1.67 & 0.107 & $9.71 \pm 3.85$ \\
\hline & Control & $10.57 \pm 3.72$ & 1.67 & 0.107 & $10.86 \pm 2.63$ \\
\hline \multirow{2}{*}{ Health adjustment } & Experimental & $9.57 \pm 2.53$ & 0.42 & 0.676 & $7 \pm 1.41$ \\
\hline & Control & $9.14 \pm 2.82$ & 0.42 & 0.676 & $7.14 \pm 1.61$ \\
\hline \multirow{2}{*}{ Social adjustment } & Experimental & $16.29 \pm 3.12$ & 0.19 & 0.851 & $11.5 \pm 2.31$ \\
\hline & Control & $16 \pm 4.71$ & 0.19 & 0.851 & $14.71 \pm 2.87$ \\
\hline \multirow{2}{*}{ Emotional adjustment } & Experimental & $15.71 \pm 5.68$ & 0.84 & 0.411 & $10.93 \pm 1.94$ \\
\hline & Control & $14.21 \pm 3.6$ & 0.84 & 0.411 & $13.29 \pm 3.85$ \\
\hline \multirow{2}{*}{ Educational and job adjustment } & Experimental & $8.93 \pm 2.34$ & 0.23 & 0.817 & $7.93 \pm 1.49$ \\
\hline & Control & $8.71 \pm 2.52$ & 0.23 & 0.817 & $7.36 \pm 1.69$ \\
\hline \multirow{2}{*}{ Total adjustment } & Experimental & $63.43 \pm 9.42$ & 1.34 & 0.193 & $47.07 \pm 6.92$ \\
\hline & Control & $58.64 \pm 9.54$ & 1.34 & 0.193 & $53.36 \pm 7$ \\
\hline
\end{tabular}

Table 3. Summary of the Analysis of Covariance for Cognitive Behavior Group Therapy in Relation to Depression, Hope and Types of Adjustment

\begin{tabular}{|c|c|c|c|c|c|c|}
\hline & Total Squares & Degrees of Freedom & Mean Square & $\mathbf{F}$ & Significance Level & Effect Size \\
\hline Depression & 39.16 & 1 & 39.16 & 1.84 & 0.187 & 0.07 \\
\hline Hope & 72.72 & 1 & 72.72 & 13.23 & 0.001 & 0.35 \\
\hline Total adjustment & 444.36 & 1 & 444.36 & 12.74 & 0.001 & 0.34 \\
\hline Adjustment at home & 35.55 & 1 & 35.55 & 4.83 & 0.038 & 0.16 \\
\hline Health adjustment & 0.22 & 1 & 0.22 & 0.09 & 0.76 & 0.004 \\
\hline Social adjustment & 76.97 & 1 & 76.97 & 15.85 & 0.001 & 0.39 \\
\hline Emotional adjustment & 44.09 & 1 & 44.09 & 4.74 & 0.039 & 0.16 \\
\hline Educational and job adjustment & 2 & 1 & 2 & 0.81 & 0.377 & 0.03 \\
\hline
\end{tabular}

due to the severity of depression in the patients with hepatitis who are not capable of achieving full recovery with the limited number of treatment sessions. Probably if the treatment is longer and further work is done on the components of depression, depression of these patients will improve. Nevertheless, to faster improve depression, using the techniques of other therapeutic approaches including the third wave of cognitive behavior therapies combined with cognitive behavior group therapy may be needed. Furthermore, in patients with hepatitis B-associated liver cirrhosis, depression is closely associated with the severity of the cirrhosis [72]. To investigate these instances, extensive research in the future is required. In a study, Elsafy et al. [73] concluded that cognitive behavior group ther- 
apy leads to decrease depression and CBT has been found to be an efficacious treatment for interferon adverse effect. In explaining the non-effectiveness of cognitive behavior group therapy in health adjustment and educational and job adjustment in this study, it can be mentioned that since depression is one of the predictor variables of adjustment with the disease (health adjustment) [74] the existence of depression in patients participating in this study may be a sign of their inadaptability or low adaptability to the disease. Besides, depression and anxiety are the side effects of the antiviral drug of interferon [9-13] which can influence the posttest results. Researchers' investigations in various sources indicate that so far, no research has been conducted regarding the effect of cognitive behavior group therapy on patients with hepatitis B. Studies carried out in this respect have dealt more with the importance of examining the depression symptoms in the medical treatment of these patients $[21,22]$. Therefore, further research in this area can help to remove some of these ambiguities.

Use of convenience sampling method to select the sample and the small number of subjects limit the generalizability of results. In addition, due to the failure to track the results, it is not clear that the results be sustained over time. Conducting research on wider samples and followup treatment design can help the generalization of results and confirmation of the stability of findings over time. Conducting similar investigations on patients with hepatitis $\mathrm{A}$ and $\mathrm{C}$ and comparing the results with the findings of the present study will lead to the discovery of an effective treatment for different types of hepatitis. Besides, comparing cognitive behavior group therapy with other group therapies such encounter group therapy or interpersonal group therapy can produce better results about the effect of group therapies on hepatitis patients. It is recommended that studies be carried out with the aim of performing a variety of psychotherapy and pharmaceutical interventions on patients with chronic diseases especially hepatitis and comparing these interventions.

\section{Acknowledgments}

Heartfelt thanks to the staff of Association for the study of liver diseases in Khorasan Razavi and all study participants for their kind cooperation. Code research: 11820701902019.This study has been registered in Iranian clinical trial website with the code IRCT2014082618937N1.

\section{Footnotes}

Authors' Contribution: Hossein Shareh and Vahid Jafarnia developed the original idea and the protocol, abstracted and analyzed and interpreted data, wrote the manuscript, and are guarantor; Zahra Robati and Fereshteh Oladi reviewed the literature and collected the clinical data; all authors finalized the manuscript and have read and approved the final manuscript.

Conflict of Interests: The authors declare no conflicts of interests. There was no financial support. The authors were responsible for all final content decisions and for the decision to submit the manuscript for publication.

Funding/Support: There was no financial support.

\section{References}

1. World Health Organization . Hepatitis B vaccines weekly epidemiological record 2004. Available from: http://www.who.int/wer.

2. Lavanchy D. Hepatitis B virus epidemiology, disease burden, treatment, and current and emerging prevention and control measures. J Viral Hepat. 2004;11(2):97-107. [PubMed:14996343].

3. Koziel MJ, Thioc CL. In: Principles and practice of infectious diseases. Mandell GL, Bennett JE, Dolin E, editors. Philadelphia: Charchill Livingstone; 2005. pp. 1864-90.Hepatitis B virus and hepatitis D virus.

4. Shepard CW, Simard EP, Finelli L, Fiore AE, Bell BP. Hepatitis B virus infection: epidemiology and vaccination. Epidemiol Rev. 2006;28:11225. doi:10.1093/epirev/mxj009. [PubMed: 16754644].

5. Alavian SM, Kabir A, Ahmadi AB, Lankarani KB, Shahbabaie MA Ahmadzad-Asl M. Hepatitis C infection in hemodialysis patients in Iran: a systematic review. Hemodial Int. 2010;14(3):253-62. doi: 10.1111/j.1542-4758.2010.00437.x. [PubMed: 20491973].

6. Jellinek MS, Snyder JB. Depression and suicide in children and adolescents. Pediatr Rev. 1998;19(8):255-64. [PubMed: 9707715].

7. Kanervisto M, Saarelainen S, Vasankari T, Jousilahti P, Heistaro S, Heliovaara M, et al. COPD, chronic bronchitis and capacity for day-to-day activities: negative impact of illness on the health-related quality of life. Chron Respir Dis. 2010;7(4):207-15. doi: 10.1177/1479972310368691. [PubMed: 21084545].

8. Frankle M. Weightlifting, weight training and injuries. Orthopedics. 1986;9(1):29. [PubMed: 3960748].

9. Rifflet H, Vuillemin E, Oberti F, Duverger P, Laine P, Garre JB, et al. [Suicidal impulses in patients with chronic viral hepatitis $\mathrm{C}$ during or after therapy with interferon alpha]. Gastroenterol Clin Biol. 1998;22(3):353-7. [PubMed: 9762223].

10. Pariante CM, Orru MG, Baita A, Farci MG, Carpiniello B. Treatment with interferon-alpha in patients with chronic hepatitis and mood or anxiety disorders. Lancet. 1999;354(9173):131-2. doi: 10.1016/S01406736(98)04793-X. [PubMed: 10408496].

11. Horikawa N, Yamazaki T, Izumi N, Uchihara M. Incidence and clinical course of major depression in patients with chronic hepatitis type $\mathrm{C}$ undergoing interferon-alpha therapy: a prospective study. Gen Hosp Psychiatry. 2003;25(1):34-8. [PubMed: 12583926].

12. Golub ET, Latka M, Hagan H, Havens JR, Hudson SM, Kapadia F, et al. Screening for depressive symptoms among HCV-infected injection drug users: examination of the utility of the CES-D and the Beck Depression Inventory. J Urban Health. 2004;81(2):278-90. [PubMed 15136661].

13. Amodio P, De Toni EN, Cavalletto L, Mapelli D, Bernardinello E, Del Piccolo F, et al. Mood, cognition and EEG changes during interferon alpha (alpha-IFN) treatment for chronic hepatitis C. J Affect Disord. 2005;84(1):93-8. doi: 10.1016/j.jad.2004.09.004. [PubMed: 15620390].

14. Bonaccorso S, Marino V, Biondi M, Grimaldi F, Ippoliti F, Maes M. Depression induced by treatment with interferon-alpha in patients af fected by hepatitis C virus. J Affect Disord. 2002;72(3):237-41. [PubMed: 12450640] 
15. Alian S, Masoudzadeh A, Khoddad T, Dadashian A, Ali Mohammadpour R. Depression in hepatitis B and C, and its correlation with hepatitis drugs consumption (interfron/lamivodin/ribaverin). Iran J Psychiatry Behav Sci. 2013;7(1):24-9. [PubMed: 24644496].

16. Snyder CR. Handbook of hope: Theory, measures, and applications. San Diego: Academic press; 2000.

17. McClement SE, Chochinov HM. Hope in advanced cancer patients. Eur J Cancer. 2008;44(8):1169-74. doi: 10.1016/j.ejca.2008.02.031. [PubMed: 18359220].

18. Sharpe L, Curran L. Understanding the process of adjustment to illness. Soc Sci Med. 2006;62(5):1153-66. doi: 10.1016/j.socscimed.2005.07.010. [PubMed: 16112783].

19. Rogers C, Keller C. Roy's adaptation model to promote physical activity among sedentary older adults. Geriatric Nurs. 2009;30(2 Suppl):21.

20. Lyons RF, Sullivan MJL, Ritvo PG, Coyne JC. Relationships in chronic illness and disability. Sage Publications Inc; 1995.

21. Dogar I, Siddiqui N, Bajwa A, Bhatti A, Haider N, Hashmi ZY. Relationship between liver diseases and levels of anxiety and depression.J Pak Psych Soc. 2009;6(2):61-4.

22. Qureshi MO, Khokhar N, Shafqat F. Severity of depression in hepatitis B and hepatitis C patients. J Coll Physicians Surg Pak. 2012;22(10):632-4. doi: 10.2012/JCPSP.632634. [PubMed: 23058145].

23. Ebrahimi DN, Bashashati M, Karbalaeian M, Keramati MR, EBRAHIMI DN, Shadman YAA. Prevalence of psychiatric disorders in hepatitis B virus carriers in Iranian charity for hepatic patients support. Hepat Mon. 2008;8(3):201-5.

24. Butler AC, Chapman JE, Forman EM, Beck AT. The empirical status of cognitive-behavioral therapy: a review of meta-analyses. Clin Psychol Rev. 2006;26(1):17-31. doi: 10.1016/j.cpr.2005.07.003. [PubMed: 16199119].

25. Leahy RL, Holland SJ, McGinn LK. Treatment plans and interventions for depression and anxiety disorders. Guilford press; 2011.

26. Vinogradov S, Yalom ID. Concise guide to group psychotherapy. American Psychiatric Pub; 1989.

27. Tiuraniemi J, Korhola J. Cognitive group therapy for depressive students: The case study. Int J Qual Stud Health Well-being. 2009;4:133-44. doi: 10.1080/17482620903098206. [PubMed: 20523883].

28. Thimm JC, Antonsen L. Effectiveness of cognitive behavioral group therapy for depression in routine practice. BMC Psychiatry. 2014;14:292. doi: 10.1186/s12888-014-0292-x. [PubMed: 25330912].

29. Patelis-Siotis I, Young LT, Robb JC, Marriott M, Bieling PJ, Cox LC, et al. Group cognitive behavioral therapy for bipolar disorder: a feasibility and effectiveness study. JAffect Disord. 2001;65(2):145-53. [PubMed: 11356238].

30. Costa RT, Cheniaux E, Range BP, Versiani M, Nardi AE. Group cognitive behavior therapy for bipolar disorder can improve the quality of life. Braz J Med Biol Res. 2012;45(9):862-8. [PubMed: 22735175].

31. Cordioli AV, Heldt E, Bochi DB, Margis R, Sousa M, Tonello JF, et al. Cognitive-behavioral group therapy in obsessive-compulsive disorder: a clinical trial. Revista Brasileira de Psiquiatria. 2002;24(3):113-20. doi: $10.1590 /$ s1516-44462002000300004.

32. Soares T, Camargo J, Pizzinato A. Effectiveness of group Cognitive Behavior Therapies for Panic Disorder: systematic review and metaanalysis. Revista Brasileira de Terapia Comportamental e Cognitiva. 2013;15(1).

33. Galassi F, Quercioli S, Charismas D, Niccolai V, Barciulli E. Cognitivebehavioral group treatment for panic disorder with agoraphobia. J Clin Psychol. 2007;63(4):409-16. doi: 10.1002/jclp.20358. [PubMed: 17279533].

34. Koffel EA, Koffel JB, Gehrman PR. A meta-analysis of group cognitive behavioral therapy for insomnia. Sleep Med Rev. 2015;19:6-16. doi: 10.1016/j.smrv.2014.05.001. [PubMed: 24931811].

35. Navarro-Bravo B, Párraga-Martinez I, Hidalgo JLT, Andrés-Pretel F, Rabanales-Sotos J. Group cognitive-behavioral therapy for insomnia: a meta-analysis. Ann Psychol. 2014;31(1):8-18.

36. Habigzang LF, Stroeher FH, Hatzenberger R, Cunha RC, Ramos Mda
S, Koller SH. Cognitive behavioral group therapy for sexually abused girls. Rev Saude Publica. 2009;43 Suppl 1:70-8. [PubMed: 19669067].

37. Beck JG, Coffey SF. Group Cognitive Behavioral Treatment for PTSD: Treatment of Motor Vehicle Accident Survivors. Cogn Behav Pract. 2005;12(3):267-77. [PubMed: 16525513].

38. Castillo DT, Lacefield K, C’De Baca J, Blankenship A, Qualls C. Effectiveness of Group-Delivered Cognitive Therapy and Treatment Length in Women Veterans with PTSD. Behav Sci (Basel). 2014;4(1):31-41. doi: 10.3390/bs4010031. [PubMed: 25379266].

39. Molassiotis A, Callaghan P, Twinn SF, Lam SW, Chung WY, Li CK. A pilot study of the effects of cognitive-behavioral group therapy and peer support/counseling in decreasing psychologic distress and improving quality of life in Chinese patients with symptomatic HIV disease. AIDS Patient Care STDS. 2002;16(2):83-96. doi: 10.1089/10872910252806135. [PubMed: 11874640].

40. Rossello JM, Jiménez-Chafey MI. Cognitive-behavioral group therapy for depression in adolescents with diabetes: a pilot study. Interamerican J Psychol. 2006;40(2):219-26.

41. McKiernan A, Steggles S, Guerin S, Carr A. A controlled trial of group cognitive behavior therapy for Irish breast cancer patients.JPsychosoc Oncol. 2010;28(2):143-56. doi: 10.1080/07347330903570511. [PubMed: 20391072].

42. Qiu J, Chen W, Gao X, Xu Y, Tong H, Yang M, et al. A randomized controlled trial of group cognitive behavioral therapy for Chinese breast cancer patients with major depression. J Psychosom Obstet Gynaecol. 2013;34(2):60-7. doi: 10.3109/0167482X.2013.766791. [PubMed: 23646866].

43. Scholten L, Willemen AM, Grootenhuis MA, Maurice-Stam H, Schuengel C, Last BF. A cognitive behavioral based group intervention for children with a chronic illness and their parents: a multicentre randomized controlled trial. BMC Pediatr. 2011;11:65. doi:10.1186/1471-243111-65. [PubMed: 21756299].

44. Macrodimitris S, Wershler J, Hatfield M, Hamilton K, Backs-Dermott B, Mothersill K, et al. Group cognitive-behavioral therapy for patients with epilepsy and comorbid depression and anxiety. Epilepsy Behav. 2011;20(1):83-8. doi: 10.1016/j.yebeh.2010.10.028. [PubMed: 21131237].

45. Arvand J, Shafiabadi A, Falsafinejad MR, Naderi N. Depression in patients with chronic hepatitis B: an experience on individual solutionfocused therapy. Gastroenterol Hepatol Bed Bench. 2012;5(3):166-8. [PubMed: 24834219].

46. Adibi P, Esmaeili A. A Multistage Group Education for Hepatitis B. Iran JMed Educ. 2001;1(4):2-8.

47. Beck AT, Steer RA, Brown GK. Beck depression inventory-II. San Antonio. 1996;78(2):490-8.

48. Zettle RD, Hayes SC. Dysfunctional control by client verbal behavior: The context of reason-giving. Anal Verbal Behav. 1986;4:30-8. [PubMed: 22477508].

49. Beck AT, Steer RA, Carbin MG. Psychometric properties of the Beck Depression Inventory: Twenty-five years of evaluation. Clin Psychol Rev. 1988;8(1):77-100.

50. Grothe KB, Dutton GR, Jones GN, Bodenlos J, Ancona M, Brantley PJ. Validation of the Beck Depression Inventory-II in a low-income African American sample of medical outpatients. Psychol Assess. 2005;17(1):110-4. doi: 10.1037/1040-3590.17.1.110. [PubMed: 15769232].

51. Wang YP, Gorenstein C. Psychometric properties of the Beck Depression Inventory-II: a comprehensive review. Rev Bras Psiquiatr. 2013;35(4):416-31. doi: 10.1590/1516-4446-2012-1048. [PubMed: 24402217].

52. Kapci EG, Uslu R, Turkcapar H, Karaoglan A. Beck Depression Inventory II: evaluation of the psychometric properties and cut-off points in a Turkish adult population. Depress Anxiety. 2008;25(10):E104-10. doi: 10.1002/da.20371. [PubMed: 17876817].

53. Fata L, Birashk B, Atefvahid MK, Dabson KS. Meaning assignment structures/schema, emotional states and cognitive processing of emotional information: comparing two conceptual frameworks. Iran 
J Psychiatr Clin Psychol. 2005;11(3):312-26.

54. Dabson KS, Mohammad KP. Psychometric characteristics of Beck depression inventory-II in patients with major depressive disorder. $J$ Rehabil. 2007;29:880-6.

55. Rajabi GR, Karju Kamaee S. Sufficiency of psychometric indexes of Persian Beck depression inventory (BDIII). J of Educ Measure. 2012;3(10):139-57.

56. Snyder CR, Harris C, Anderson JR, Holleran SA, Irving LM, Sigmon ST, et al. The will and the ways: development and validation of an individual-differences measure of hope.J Pers Soc Psychol. 1991;60(4):570-85. [PubMed: 2037968].

57. Snyder CR, Lopez SJ, Pedrotti JT. Positive psychology: The scientific and practical explorations of human strengths. Sage Publications; 2010.

58. Bonab BG, Lavasani M, Rahimi H. Hope, Purpose in Life, and Mental Health in College Students. Int J Human. 2007;5(5).

59. Kermani Z, Khodapanahi M, Heidari M. psychometrics features of the Snyder Hope Scale. J Appl Psychol. 2011;5(19):7-23.

60. Bell HM. The adjustment inventory: student form. Palo Alto: Consulting Psychologist Press; 1962.

61. Bell HM. The adjustment inventory (adult form). Palo Alto: Consulting Psychologist Press; 1961

62. Poorseyed SR, Habibollahi S, Faramarzi S. Effectiveness of life skills educational program on blind and low-vision university students compatibility. Educ Strateg Med Sci. 2010;3(1):3-4.

63. Khatibian M, Shakerian A. The effectiveness of cognitive behavioral group therapy on decreasing depression, anxiety and stress in breast cancer women admitted to Ahwaz Medical Sciences Hospitals. Sci J Kurdistan Univ Med Sci. 2014;19(4):91-9.

64. Oladi F, Bayazi MH, Dargahi M, Neyshabouri M. Cognitive Behavioral Group Therapy and Coping Styles in patients with Acute Coronary Heart Disease. Iran Rehabil J. 2014;12(21).

65. Mohammadi Garavand R, Zeini Hassanvand N, Nokani M. Investigation of efficacy of cognitive- behavioral group therapy in reducing symptoms of depression in patients with coronary heart disease.
Translat Med Biotechnol. 2014;2(2):57-66.

66. Hassanzade R, Janbabaei G, Salavati M, Moonesi F, Khaleghi S, Siamian H. Evaluation of group-therapy efficacy by cognitive-behavioral therapy method for promoting general health among breast cancer patients. Health Med. 2012;6:1541-6.

67. Rustoen T, Cooper BA, Miaskowski C. A longitudinal study of the effects of a hope intervention on levels of hope and psychological distress in a community-based sample of oncology patients. Eur J Oncol Nurs. 2011;15(4):351-7. doi: 10.1016/j.ejon.2010.09.001. [PubMed: 20870459].

68. Strawbridge WJ, Cohen RD, Shema SJ, Kaplan GA. Frequent attendance at religious services and mortality over 28 years. Am J Public Health. 1997;87(6):957-61. [PubMed: 9224176].

69. Snyder M. The discursive proportion of hope: a qualitative analysis of cancer patients speech. Qual Health Res. 2006;12(2).

70. Lorig KR, Sobel DS, Stewart AL, Brown BJ, Bandura A, Ritter P, et al. Evidence suggesting that a chronic disease self-management program can improve health status while reducing hospitalization: a randomized trial. Med Care. 1999;37(1):5-14. [PubMed: 10413387].

71. Touzandeh JH, Sedighi K, Nejat H, Kamalpour N. An investigation of relative effectiveness of cognitive-behavioral trainings of self-esteem on social adjustment of male juniors of high school.J Sci Res Train Sci. 2008;1(16):41-56.

72. Zhu HP, Gu YR, Zhang GL, Su YJ, Wang KE, Zheng YB, et al. Depression in patients with chronic hepatitis $B$ and cirrhosis is closely associated with the severity of liver cirrhosis. Exp Ther Med. 2016;12(1):405-9. doi: 10.3892/etm.2016.3271. [PubMed: 27347069].

73. Elsafy ER, Abu-Hendy W, Abouhashim HM, Fouad HA. Depression in chronic hepatitis $C$ patients and the role of cognitive behavioral therapy in its treatment. Egypt J Psychiatr. 2014;35(3):179.

74. Lernmark B, Persson B, Fisher L, Rydelius PA. Symptoms of depression are important to psychological adaptation and metabolic control in children with diabetes mellitus. Diabet Med. 1999;16(1):14-22. [PubMed: 10229288]. 